\title{
In vitro methods to evaluate the mechanical behavior of teeth restored with post and core: a structured review
}

\section{Métodos in vitro para avaliação do comportamento mecânico de dentes restaurados com pino e núcleo: uma revisão de literatura}

\author{
Sara Fraga* \\ lana Lamadrid Aurélio* \\ Marília Pivetta Rippe* \\ Osvaldo Bazzan Kaizer* \\ Luiz Felipe Valandro*
}

\begin{abstract}
Objective: to critically assess in vitro methods used to evaluate the mechanical behavior of endodontically treated teeth restored with intra-radicular posts and cores. Literature review: a literature search of in vitro studies was conducted in PubMed database using the search terms: ("endodontic*" OR "intracanal post") AND ("fracture" OR "resistance" OR "load" OR "strength"). A filter for publication date was set to return studies from the last five years (from October 2010 to October 2015). The research strategy resulted in 1,556 studies. After the analysis of the eligibility criteria, 92 articles were included in a descriptive analysis. Human upper central incisors were used most frequently. The natural mobility of teeth was simulated using an artificial periodontal ligament in $66.7 \%$ of the studies. In $32.2 \%$ of the studies, the load to fracture was applied directly to the core. Thermocycling was performed in $27.2 \%$ of the studies. Cyclic loading was used in 38\% of the studies. Final considerations: periodontal ligament simulation, thermocycling and cyclic loads are some methods that have been employed to approximate laboratory studies to the clinical conditions that teeth restored intra-radicular posts and cores are submitted. Novel test methodologies, such as step-test and staircase approach, have been used to evaluate the fatigue behavior of this systems. However, it is important do highlight that, considering the context in which most of the included studies were performed, the extrapolation of the results to the clinical practice should be made carefully.
\end{abstract}

Keywords: Fatigue. In Vitro Techniques; Tooth, Nonvital. Dental Dowels.

\section{Introduction}

By means of in vitro studies, it is possible to standardize and to isolate a variable of interest, elucidating any doubts prior to conducting clinical studies $^{1}$. However, over the past few decades, the validity of some in vitro dental materials studies has been questioned due to the variability in the methodological parameters, the lack of representativeness of the clinical mechanism of failure and the poor correlation with clinical behavior ${ }^{2,3}$. Despite this, and considering that many issues related to restorative dental materials are difficult to evaluate in clinical studies because of high costs and ethical considerations ${ }^{4}$, the question that arises is: How can one simulate in laboratory the clinical conditions that dental materials are submitted?

Initially, it is very important to establish differences among in vitro studies. According to Kelly et $\mathrm{al}^{2}$ (2012), in vitro studies can be categorized into two main groups: tests involving the measurement of physical properties; and tests aiming to simulate the clinical behavior ${ }^{2}$. There are standardized tests of mechanical and chemical properties in the first group, to include strength, fracture toughness, hardness, and thermal expansion, all of which use simplified specimens. The second group uses tests that try to simulate the oral environment, to include parameters such as loading, temperature changes and humidity, usually employing specimens that are more complex and clinically more realis-

Dental Science Post Graduate Program, Universidade Federal de Santa Maria, Santa Maria, Rio Grande do Sul, Brazil.

Department of Restorative Dentistry, Universidade Federal de Santa Maria, Santa Maria, Rio Grande do Sul, Brazil. 
$\mathrm{tic}^{2}$. Therefore, the type of information that is desired is crucial for selecting the most suitable in vitro methodology and test parameters.

In contemporary dentistry, the choice of the best restorative treatment for endodontically treated teeth is still a question. Many factors may affect the longevity of pulpless teeth, such as the quantity of remain dentin; length, material and design of the post; apical seal; and position of the tooth in the $\operatorname{arch}^{5}$. Laboratory studies have been widely employed to evaluate the impact of these factors on the mechanical behavior of endodontically treated teeth, since clinical trials are time-consuming, costly and standardization is sometimes difficult ${ }^{6}$. Different methodologies, involving different test parameters, have been applied in laboratory studies aiming to predict the clinical behavior of endodontically treated teeth, to include fatigue tests, mechanical cycling and thermocycling.

The purpose of this structured review was to compile and to critically assess the laboratory methods that have been employed to evaluate the mechanical behavior of endodontically treated teeth restored with intra-radicular posts and cores, including direct posts, such as glass fiber, and indirect cast posts.

\section{Literature review}

\section{Strategy search}

A literature search of in vitro studies was conducted in the PubMed database using the sear- ch terms of: ("endodontic*" OR "intracanal post") AND ("fracture" OR "resistance" OR "load" OR "strength"). The search was made in 30 October 2015. A filter for publication date was set to return studies from the last five years (from October 2010 to October 2015). The inclusion criteria were: fracture strength studies containing at least one group with endodontically treated teeth restored with an intracanal post and core (irrespective of being a prefabricated post, such as glass fiber, or an indirect cast post); studies using human teeth of the secondary dentition with mature radicular apices or studies using animal teeth. The following manuscripts were excluded: review articles; studies of adhesive strength and finite element analysis; or in vitro studies using roots with a vertical fracture before the test and re-attached fragments. Only manuscripts in the English language were considered.

\section{Results and discussion}

Figure 1 shows the flow diagram that summarizes the study selection process according to the PRISMA Statement ${ }^{7}$. The search strategy resulted in 1,556 potentially eligible studies, on which 1,453 papers were excluded because they did not meet the eligibility criteria. The 103 remaining studies were selected for full-text analysis, from which 11 papers were excluded. Thus, a total of 92 laboratory studies fulfilled all of the inclusion criteria and were included in this review.

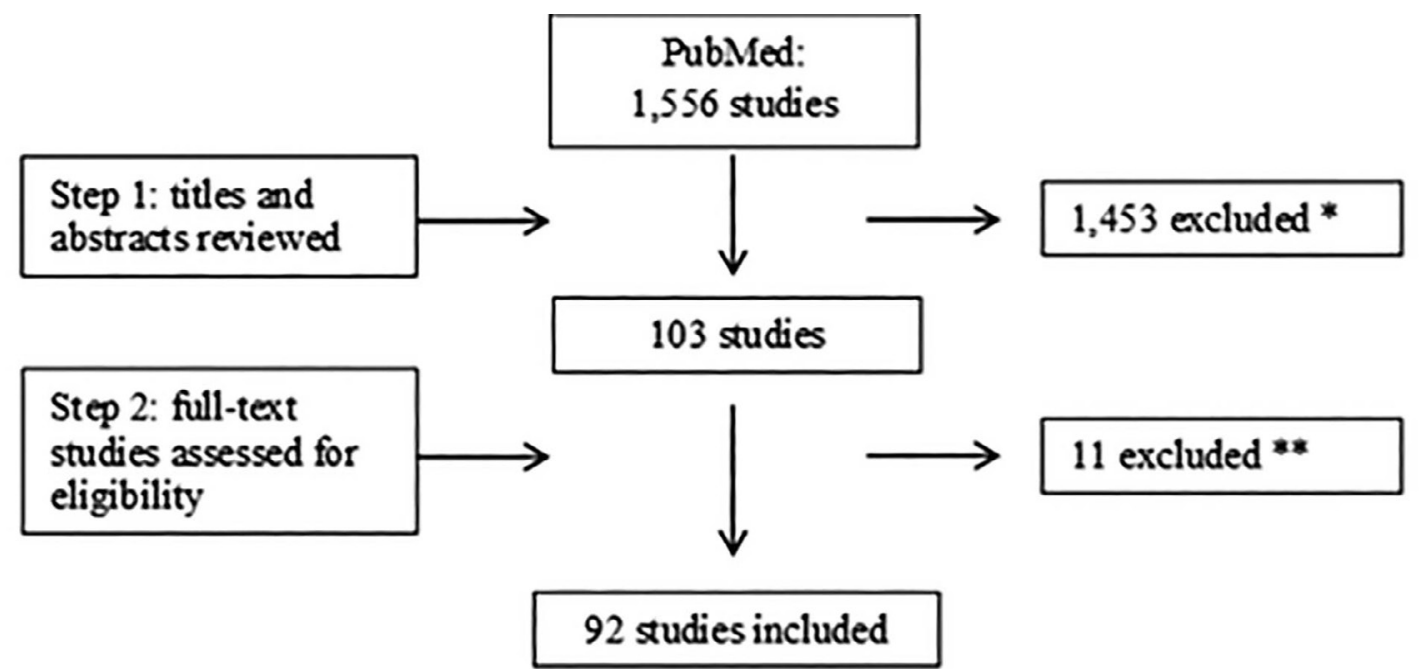

* Exclusions: did not evaluate the topic of interest $(n=731)$; adhesive strength sudies $(n=351)$; clinical case report $(n=139)$; no core $(n=85)$; clinical studies $(n=69)$; review sudies $(n=59)$; studies using primary or immature teeth $(n=16)$ : studies using teeth with reattached frament $(n=$

** Exclusions no English language $(n=5)$; no core $(n=4)$; no post $(n=1)$; adhesive strength study $(\mathrm{n}=1)$. 
The main methodological characteristics of the included studies are summarized in Table 1. A critical assessment regarding the laboratory me-

thods and the most common test parameters employed in the included studies are presented and discussed.

Table 1 - Main methodological information of the included studies

\begin{tabular}{|c|c|c|c|c|}
\hline Author & Tooth type & $\begin{array}{l}\text { Periodontal } \\
\text { ligament }\end{array}$ & Restoration (Material) & Loading type \\
\hline Amarnath et al. ${ }^{8}$ (2015) & H-LPM & no & just core & monotonic \\
\hline Bilgin et al. ${ }^{9}(2015)$ & H-LPM & no & just core & monotonic \\
\hline Bitter et al. ${ }^{10}(2015)$ & $\mathrm{H}-\mathrm{UCl}$ & silicone & just core & thermomechanical cycling + monotonic \\
\hline Broch et al. ${ }^{11}(2015)$ & B-I & polyether & crown (metal) & $\begin{array}{l}\text { monotonic vs. mechanical cycling }+ \\
\text { monotonic }\end{array}$ \\
\hline Dastjerdi et al. ${ }^{12}$ (2015) & $\mathrm{H}-\mathrm{UCl}$ & no & crown (metal) & thermomechanical cycling + monotonic \\
\hline Farina et al. ${ }^{13}$ (2015) & $\mathrm{H}-\mathrm{UC}$ & Silicone & crown (metal) & monotonic \\
\hline Gaikwad et al. ${ }^{14}$ (2015) & $\mathrm{H}-\mathrm{UCl}$ & no & just core & monotonic \\
\hline Güth et al. ${ }^{15}$ (2015) & $\mathrm{H}-\mathrm{UM}$ & no & crown (all-ceramic) & just mechanical cycling (step-test) \\
\hline Khaledi et al. ${ }^{16}(2015)$ & $\mathrm{H}-\mathrm{UCl}$ & silicone & just core & monotonic \\
\hline Kumar et al. ${ }^{17}(2015)$ & $\mathrm{H}-\mathrm{UCl}$ & no & just core & monotonic \\
\hline Kurthukoti et al. ${ }^{18}$ (2015) & $\mathrm{H}-\mathrm{UCl}$ & silicone & just core & monotonic \\
\hline Maroulakos et al. ${ }^{19}(2015)$ & $\mathrm{H}-\mathrm{UI} ; \mathrm{H}-\mathrm{UC}$ & no & crown (metal) & thermomechanical cycling + monotonic \\
\hline Muangamphan et al. ${ }^{20}(2015)$ & $\mathrm{H}-\mathrm{UI} ; \mathrm{H}-\mathrm{UC}$ & silicone & crown (metal) & monotonic \\
\hline Samran et al. ${ }^{21}$ (2015) & H-LPM & silicone & crown (metal) & monotonic \\
\hline Schmidlin et al. ${ }^{22}$ (2015) & H-UPM & silicone & $\begin{array}{l}\text { crown and endocrown (all- } \\
\text { ceramic) }\end{array}$ & monotonic \\
\hline Sonkesriya et al. ${ }^{23}$ (2015) & $\mathrm{H}-\mathrm{UCl}$ & no & just core & monotonic \\
\hline Sreedevi et al. ${ }^{24}$ (2015) & $\mathrm{H}-\mathrm{UCl}$ & no & crown (metal) & monotonic \\
\hline Vachhani and Asnani ${ }^{25}$ (2015) & $\mathrm{H}-\mathrm{UCl}$ & no & just core & monotonic \\
\hline Zhang et al. ${ }^{26}$ (2015) & $\mathrm{H}-\mathrm{UCl}$ & silicone & crown (metal) & monotonic \\
\hline Abdulrazzak et al. ${ }^{27}$ (2014) & $\mathrm{H}-\mathrm{UCl}$ & silicone & crown (metal) & thermocycling + monotonic \\
\hline Aggarwal et al. ${ }^{28}$ (2014) & H-LPM & $\begin{array}{l}\text { epoxy resin } \\
\text { liner }\end{array}$ & crown (metaloceramic) & mechanical cycling + monotonic \\
\hline Alharbi et al. ${ }^{29}(2014)$ & $\mathrm{H}-\mathrm{UC}$ & no & crown (all-ceramic) & $\begin{array}{l}\text { monotonic vs. mechanical cycling + } \\
\text { monotonic }\end{array}$ \\
\hline Amin et al..$^{30}(2014)$ & $\mathrm{H}-\mathrm{UCl}$ & no & just core & thermocycling + monotonic \\
\hline Chieruzzi et al. ${ }^{31}$ (2014) & $\mathrm{H}-\mathrm{I} ; \mathrm{H}-\mathrm{C}$ & no & just core & monotonic \\
\hline Franco et al. ${ }^{32}$ (2014) & $\mathrm{H}-\mathrm{UC}$ & no & crown (metal) & monotonic \\
\hline Furuya et al. ${ }^{33}$ (2014) & H-UPM & silicone & crown (metal) & monotonic \\
\hline Gomes et al. ${ }^{34}$ (2014) & H-LPM & polyether & $\begin{array}{l}\text { crown (indirect composite } \\
\text { resin) }\end{array}$ & mechanical cycling + monotonic \\
\hline Krastl et al. ${ }^{35}(2014)$ & H-LPM & silicone & crown (direct composite resin) & thermomechanical cycling + monotonic \\
\hline Pereira et al. ${ }^{36}(2014)$ & $\mathrm{H}-\mathrm{UC}$ & silicone & crown (metal) & mechanical cycling + monotonic \\
\hline $\begin{array}{l}\text { Ramírez-Sebastià et al. }{ }^{37} \\
(2014)\end{array}$ & $\mathrm{H}-\mathrm{UCl}$ & no & $\begin{array}{l}\text { crown and endocrown } \\
\text { (all-ceramic and indirect } \\
\text { composite resin) }\end{array}$ & thermomechanical cycling + monotonic \\
\hline Rippe et al. ${ }^{38}(2014)$ & $\begin{array}{l}\text { H-UC; } \\
\text { H-LC; } \\
\text { H-LPM }\end{array}$ & polyether & just core & $\begin{array}{l}\text { monotonic vs. mechanical cycling }+ \\
\text { monotonic }\end{array}$ \\
\hline Santos-Filho et al. ${ }^{39}(2014)$ & B-I & polyether & crown (metal) & monotonic \\
\hline Singh and Thareja ${ }^{40}(2014)$ & $\mathrm{H}-\mathrm{UCl}$ & no & crown (metaloceramic) & monotonic \\
\hline Soundar et al. ${ }^{41}$ (2014) & $\mathrm{H}-\mathrm{UCl}$ & no & crown (metal) & monotonic \\
\hline Tey and Lui ${ }^{42}(2014)$ & $\mathrm{H}-\mathrm{UCl}$ & silicone & crown (metal) & thermocycling + monotonic \\
\hline Veríssimo et al. ${ }^{43}$ (2014) & B-I & polyether & crown (metal and all-ceramic) & monotonic \\
\hline Wandscher et al. ${ }^{44}$ (2014) & B-I & polyether & crown (metal) & just mechanical cycling (survival test) \\
\hline Aggarwal et al. ${ }^{45}$ (2013) & $\mathrm{H}-\mathrm{UCl}$ & silicone & just core & thermocycling + monotonic \\
\hline Ambica et al. ${ }^{46}(2013)$ & $\mathrm{H}-\mathrm{UCl}$ & silicone & just core & $\begin{array}{l}\text { monotonic vs. thermomechanical cycling }+ \\
\text { monotonic }\end{array}$ \\
\hline Bacchi et al. ${ }^{47}$ (2013) & $\mathrm{H}-\mathrm{UCl}$ & silicone & crown (metal) & monotonic \\
\hline Balkaya and Birdal ${ }^{48}$ (2013) & $\mathrm{H}-\mathrm{UCl}$ & silicone & just metal coping & monotonic \\
\hline Barcellos et al. ${ }^{49}(2013)$ & $\mathrm{H}-\mathrm{UC}$ & silicone & crown (metal) & mechanical cycling + monotonic \\
\hline Carlini-Júnior et al. ${ }^{50}$ (2013) & B-I & polyether & crown (metal) & monotonic \\
\hline Evangelinaki et al. ${ }^{51}$ (2013) & $\mathrm{H}-\mathrm{UC}$ & silicone & $\begin{array}{l}\text { crown (metaloceramic and } \\
\text { all-ceramic) }\end{array}$ & monotonic \\
\hline Hou et al. ${ }^{52}(2013)$ & H-LPM & silicone & crown (metal) & mechanical cycling + monotonic \\
\hline Jiangkongkho et al. ${ }^{53}$ (2013) & H-LPM & silicone & $\begin{array}{l}\text { crown (metal and composite } \\
\text { resin) }\end{array}$ & monotonic \\
\hline
\end{tabular}


cont...

\begin{tabular}{|c|c|c|c|c|}
\hline Jindal et al..$^{54}(2013)$ & $\mathrm{H}-\mathrm{UCl}$ & silicone & crown (metal) & monotonic \\
\hline Kaya and $\operatorname{Ergun}^{55}$ (2013) & $\mathrm{H}-\mathrm{UCl}$ & polyether & crown (metal) & monotonic \\
\hline Mobilio et al. ${ }^{56}$ (2013) & H-LPM & polyether & just metal coping & thermomechanical cycling + monotonic \\
\hline Naumann et al..$^{57}$ (2013) & $\mathrm{H}-\mathrm{UCl}$ & silicone & $\begin{array}{l}\text { two-unit anterior cantilever- } \\
\text { fixed partial denture (all- } \\
\text { ceramic) }\end{array}$ & thermomechanical cycling + monotonic \\
\hline Ozcan and Sahin ${ }^{58}(2013)$ & $\mathrm{H}-\mathrm{UCl}$ & silicone & crown (all-ceramic) & thermocycling + monotonic \\
\hline Rippe et al..$^{59}(2013)$ & $\begin{array}{l}\text { H-LPM; } \\
\text { H-LC; } \\
\text { H-UC }\end{array}$ & silicone & just core & monotonic \\
\hline Samran et al. ${ }^{60}(2013)$ & H-LPM & no & crown (metal) & mechanical cycling + monotonic \\
\hline Torres-Sánchez et al. ${ }^{61}$ (2013) & H-LPM & polysulfide & crown (metal) & monotonic \\
\hline Zicari et al..$^{62}$ (2013) & H-UPM & no & crown (all-ceramic) & mechanical cycling + monotonic \\
\hline Aggarwal et al. ${ }^{63}$ (2012) & H-LPM & $\begin{array}{l}\text { epoxy resin } \\
\text { liner }\end{array}$ & $\begin{array}{l}\text { crown (indirect composite } \\
\text { resin) }\end{array}$ & mechanical cycling + monotonic \\
\hline Akman et al. ${ }^{64}$ (2012) & $\begin{array}{l}\text { H-UC; } \\
\text { H-UPM }\end{array}$ & silicone & $\begin{array}{l}\text { two-unit cantilever-fixed } \\
\text { partial denture (metal) }\end{array}$ & thermocycling + monotonic \\
\hline Biacchi and Basting ${ }^{65}$ (2012) & H-LM & no & $\begin{array}{l}\text { crown and endocrown (all- } \\
\text { ceramic) }\end{array}$ & monotonic \\
\hline Borelli et al. ${ }^{66}(2012)$ & $\mathrm{H}-\mathrm{UCl}$ & polyether & just core & thermocycling + monotonic \\
\hline Castro et al. ${ }^{67}(2012)$ & $\begin{array}{l}\text { H-UI; } \\
\text { H-UC; } \\
\text { H-UM; } \\
\text { H-LM }\end{array}$ & polyether & crown (metal) & monotonic \\
\hline Costa et al. ${ }^{68}(2012)$ & $\begin{array}{l}\text { H-UPM; } \\
\text { H-LPM }\end{array}$ & silicone & just core & mechanical cycling + monotonic \\
\hline Fragou et al. ${ }^{69}$ (2012) & $\mathrm{H}-\mathrm{UC}$ & silicone & $\begin{array}{l}\text { crown (metalceramic and all- } \\
\text { ceramic) }\end{array}$ & monotonic \\
\hline Hegde et al. ${ }^{70}(2012)$ & $\mathrm{H}-\mathrm{UCl}$ & silicone & crown (metal) & monotonic \\
\hline Jindal et al..$^{71}(2012)$ & $\mathrm{H}-\mathrm{UCl}$ & silicone & crown (metal) & monotonic \\
\hline Kaur et al. ${ }^{72}$ (2012) & $\mathrm{H}-\mathrm{UCl}$ & silicone & crown (metal) & monotonic \\
\hline Kumagae et al. ${ }^{73}$ (2012) & H-LPM & silicone & just core & monotonic \\
\hline Mankar et al..$^{74}(2012)$ & H-UPM & no & just core & monotonic \\
\hline Mehrvarzfar et al. ${ }^{75}$ (2012) & $\mathrm{H}-\mathrm{UCl}$ & polyether & just core & monotonic \\
\hline Nie et al. ${ }^{76}(2012)$ & H-LPM & silicone & crown (metal) & $\begin{array}{l}\text { monotonic vs mechanical cycling }+ \\
\text { monotonic }\end{array}$ \\
\hline Rosa et al. ${ }^{77}$ (2012) & B-I & no & just core & mechanical cycling + monotonic \\
\hline Rotunno and Rotunno ${ }^{78}$ (2012) & $\mathrm{H}-\mathrm{UCl}$ & no & just core & monotonic \\
\hline $\begin{array}{l}\text { Schiavetti and Sannino } \\
\text { (2012) }\end{array}$ & H-PM & no & just core & monotonic \\
\hline Sterzenbach et al. ${ }^{80}(2012)$ & $\mathrm{H}-\mathrm{UCl}$ & silicone & crown (all-ceramic) & $\begin{array}{l}\text { monotonic vs thermomechanical cycling + } \\
\text { monotonic }\end{array}$ \\
\hline Tunjan et al. ${ }^{81}$ (2012) & $\mathrm{H}-\mathrm{UCl}$ & silicone & $\begin{array}{l}\text { two-unit anterior cantilever- } \\
\text { fixed partial denture (all- } \\
\text { ceramic) }\end{array}$ & thermomechanical cycling + monotonic \\
\hline Zicari et al. ${ }^{82}$ (2012) & H-UPM & no & just core & mechanical cycling + monotonic \\
\hline Ayad et al. ${ }^{83}$ (2011) & $\mathrm{H}-\mathrm{UCl}$ & silicone & crown (metal) & monotonic \\
\hline Carlini-Júnior et al..$^{84}$ (2011) & B-I & polyether & crown (metal) & monotonic \\
\hline Kathuria et al. ${ }^{85}$ (2011) & $\mathrm{H}-\mathrm{UCl}$ & silicone & just core & thermocycling + monotonic \\
\hline Khatter et al. ${ }^{86}$ (2011) & $\mathrm{H}-\mathrm{UCl}$ & silicone & just core & thermocycling + monotonic \\
\hline Li et al. ${ }^{87}(2011)$ & $\mathrm{H}-\mathrm{UCl}$ & silicone & crown (metal) & thermomechanical cycling + monotonic \\
\hline Makade et al..$^{88}$ (2011) & $\mathrm{H}-\mathrm{UCl}$ & silicone & just core & monotonic \\
\hline Mangold and Kern ${ }^{89}$ (2011) & H-LPM & no & crown (metal) & thermomechanical cycling + monotonic \\
\hline Naumann et al..$^{90}(2011)$ & $\mathrm{H}-\mathrm{UCl}$ & silicone & crown (all-ceramic) & thermomechanical cycling + monotonic \\
\hline Ni et al. ${ }^{91}(2011)$ & H-UPM & silicone & crown (metal) & thermomechanical cycling + monotonic \\
\hline Nothdurft et al..$^{92}$ (2011) & B-I & no & crown (metal) & $\begin{array}{l}\text { monotonic vs thermomechanical cycling + } \\
\text { monotonic }\end{array}$ \\
\hline Santana et al..$^{93}$ (2011) & $\mathrm{H}-\mathrm{LM}$ & polyether & crown (metal) & monotonic \\
\hline Santini et al. ${ }^{94}$ (2011) & B-I & no & just core & mechanical cycling + monotonic \\
\hline Sherfudhin et al. ${ }^{95}$ (2011) & H-LPM & silicone & crown (all-ceramic) & mechanical cycling + monotonic \\
\hline Silva et al. ${ }^{96}(2011)$ & B-I & polyether & crown (metal) & mechanical cycling + monotonic \\
\hline Solomon and Osman ${ }^{97}$ (2011) & $\mathrm{H}-\mathrm{UI}$ & no & just core & monotonic \\
\hline Chuang et al. ${ }^{98}$ (2010) & $\mathrm{H}-\mathrm{UCl}$ & & crown (metaloceramic) & thermocycling + monotonic \\
\hline Silva et al. ${ }^{99}(2010)$ & B-I & polyether & crown (metal and all-ceramic) & monotonic \\
\hline
\end{tabular}




\section{Specimen Preparation}

\section{Type of tooth}

Human upper central incisors were used most frequently (43.3\% of the included studies), followed by human lower pre-molars (17.8\%), human upper canines $(7.8 \%)$, human upper pre-molars $(6.7 \%)$ and human lower and upper molars $(2.2 \%)$. A combination of different types of human teeth was used in $10.0 \%$ of the studies. The literature indicates non-axial forces as a risk for fatigue fracture of teeth, cement, or restorative material ${ }^{100}$. However, the position of the tooth in the arch must be determinant. The function of posterior teeth is to accept forces applied during closure of the mouth effectively. These forces are directed through the long axes of the posterior teeth and, then, dissipated efficiently. The anterior teeth, however, are not well positioned to accept heavy forces. They are normally positioned at a labial angle to the direction of closure, and accept well the forces of eccentric mandibular movements ${ }^{101}$.

Bovine incisors were used in $12.2 \%$ studies. The use of animal teeth in in vitro studies has been motivated by the difficulty in obtaining healthy human teeth in sufficient quantity, due to the risk of infection and for ethical considerations. According to Teruel et al. ${ }^{102}$ (2015), bovine teeth should be the first choice as substitutes for human teeth in research on the basis of similar chemical compositions. However, differences in morphological, chemical composition and physical properties between these kinds of teeth must be considered when interpreting results obtained from any experiment using bovine tooth substrate ${ }^{103}$.

\section{Periodontal ligament simulation}

Periodontal ligament (PDL) is important for the mechanisms of stress distribution over teeth. The natural mobility of the tooth in the alveolar bone was simulated using an artificial PDL in $66.7 \%$ of the studies, reproducing a more realistic clinical situation. Materials used to simulate the PDL included: silicon $(71.7 \%)$, polyether $(23.3 \%)$, epoxy resin liner (3.3\%) and polysulfide (1.7\%). For the strength test, samples were usually included in self-curing acrylic resin, epoxy resin and polystyrene resin.

Soares et al. ${ }^{104}$ (2005) evaluated the influence of the embedding material (acrylic resin; polystyrene resin) and PDL simulation (absence of ligament or presence of polyether, polysulfide, or polyurethane) on the fracture behavior of bovine teeth. A significant difference was found among the modes of fracture, mainly in relation to the presence of a simulated PDL. When teeth were embedded directly in resin, stresses seemed to be concentrated around the tooth region localized at the top of the embe- dding material. However, rigid attachment of the root is not found in nature, since the PDL transfers stresses applied to the coronal structure to all the root surface.

\section{Core/Crown restoration}

In $32.2 \%$ of the studies, the load was applied directly in the core. A crown was used in 59\% of the studies, followed by crown and endocrown (3.3\%), two-unit cantilever-fixed partial denture $(3.3 \%)$ and just metal coping $(2.2 \%)$.

Regarding the crowns and endocrowns, the most frequent material used was metal (61\%), followed by all-ceramic crowns (18.6\%), metaloceramic (5.1\%), indirect composite resin (3.4\%), and a combination of all ceramic and metaloceramic (3.4\%), all ceramic and metal crown (3.4\%), all-ceramic and indirect composite resin (1.7\%), metal and indirect composite resin $(1.7 \%)$ and direct composite resin (1.7\%). The use of metal crowns, even considering that the human upper central incisor was the most used type of tooth, may be related to the lower laboratory costs when compared with other prosthetic materials, like all-ceramic crowns.

The use of a coronal restoration in tests involving the fracture resistance of endodontically treated teeth restored with intracanal posts has been questioned. A crown creates a ferrule effect and different load distribution when placed over a core buildup if the margins encircle a sound dentin collar ${ }^{105}$. It may obscure the effects of different buildup techniques ${ }^{16}$. However, testing post-and-core preparations without placement of a crown would not have reflected clinical practice.

\section{Loading protocol}

The loading protocol applied in the studies is summarized in Table 2. The parameters of mechanical cycling and thermocycling are summarized in Table 3.

Most of the included studies classified the failure in repairable (favorable) and non-repairable (unfavorable), regardless of the loading protocol adopted. Generally, failures at or above the simulated bone level were considered favorable; while fractures below the simulated bone level were considered unfavorable. The possibility of repairing the tooth after the failure was also been use as a criterion to classify the failure mode in clinical trials. Root fractures or nonrepairable fractures of the post/core restoration leading to tooth extraction have been considered absolute failures, while loss of post retention or repairable fractures of the core without further weakening of the tooth have been considered relative failures ${ }^{106-108}$. 
Table 2 - Loading protocol applied in the included studies

\begin{tabular}{|c|c|}
\hline Loading & $\%$ (number of studies) \\
\hline monotonic & $51.1 \%$ (47 studies) \\
\hline mechanical cycling + monotonic & $15.2 \%$ (14 studies)* \\
\hline thermocycling + monotonic & $10.9 \%$ (10 studies)* \\
\hline thermomechanical cycling + monotonic & $13 \%(12 \text { studies })^{*}$ \\
\hline comparison: monotonic vs thermomechanical cycling + monotonic & $3.3 \%(3 \text { studies })^{*}$ \\
\hline comparison: monotonic vs mechanical cycling + monotonic & $4.3 \%(4 \text { studies })^{*}$ \\
\hline just mechanical cycling & $2.2 \%$ (2 studies) \\
\hline TOTAL & $100 \%$ (92 studies) \\
\hline
\end{tabular}

${ }^{*}$ Cycling aimed to promote aging.

Table 3 - Parameters of mechanical and thermocycling

\begin{tabular}{|c|c|c|c|c|c|c|}
\hline \multirow[b]{2}{*}{ Author (year) } & \multicolumn{3}{|c|}{ Mechanical cycling } & \multicolumn{3}{|c|}{ Thermocycling } \\
\hline & Load amplitude & Number of cycles & Frequency & Temperature & $\begin{array}{l}\text { Dwell } \\
\text { time }\end{array}$ & $\begin{array}{c}\text { Number } \\
\text { cycles }\end{array}$ \\
\hline Bitter et al. ${ }^{10}(2015)$ & $50 \mathrm{~N}$ & $1,200,000$ & $n r$ & $5^{\circ} \mathrm{C}$ to $55^{\circ} \mathrm{C}$ & $120 \mathrm{~s}$ & 6,000 \\
\hline Broch et al. ${ }^{11}$ (2015) & $88 \mathrm{~N}$ & 100,000 & $2.2 \mathrm{~Hz}$ & - & - & - \\
\hline Dastjerdi et al. ${ }^{12}$ (2015) & $50 \mathrm{~N}$ & 250,000 & $n r$ & $5^{\circ} \mathrm{C}$ to $55^{\circ} \mathrm{C}$ & $60 s$ & 500 \\
\hline Güth et al. ${ }^{15}$ (2015) & $\begin{array}{l}200 \mathrm{~N} \\
400-600-800-1,000-1,200-1,400 \mathrm{~N}\end{array}$ & $\begin{array}{l}5,000 \text { cycles } \\
10,000 \text { cycles each step }\end{array}$ & $5 \mathrm{~Hz}$ & - & - & - \\
\hline Maroulakos et al. ${ }^{19}$ (2015) & $50 \mathrm{~N}$ & 50,000 & $2 \mathrm{~Hz}$ & $5^{\circ} \mathrm{C}$ to $55^{\circ} \mathrm{C}$ & $16 \mathrm{~s}$ & 6,000 \\
\hline Abdulrazzak et al. ${ }^{21}$ (2014) & & - & - & $5^{\circ} \mathrm{C}$ to $55^{\circ} \mathrm{C}$ & $30 \mathrm{~s}$ & 500 \\
\hline Aggarwal et al. ${ }^{28}$ (2014) & $60 \mathrm{~N}$ & 150,000 & $50 \mathrm{~Hz}$ & - & - & - \\
\hline Alharbi et al. ${ }^{29}(2014)$ & $250 \mathrm{~N}$ & $1,000,000$ & $n r$ & - & - & - \\
\hline Amin et al. ${ }^{30}(2014)$ & - & - & - & $5^{\circ} \mathrm{C}$ to $55^{\circ} \mathrm{C}$ & $30 \mathrm{~s}$ & 3,000 \\
\hline Gomes et al. ${ }^{34}$ (2014) & $40 \mathrm{~N}$ & $1,200,000$ & $2 \mathrm{~Hz}$ & - & - & - \\
\hline Krastl et al. ${ }^{35}$ (2014) & $49 \mathrm{~N}$ & $1,200,000$ & $1.7 \mathrm{~Hz}$ & $5^{\circ} \mathrm{C}$ to $50^{\circ} \mathrm{C}$ & $n r$ & 3,000 \\
\hline Pereira et al..$^{36}(2014)$ & $30 N$ & 250,000 & $2.6 \mathrm{~Hz}$ & - & - & - \\
\hline Ramírez-Sebastià et al. ${ }^{37}$ (2014) & $49 N$ & 600,000 & $n r$ & $5^{\circ} \mathrm{C}$ to $55^{\circ} \mathrm{C}$ & $n r$ & 1,500 \\
\hline Rippe et al. ${ }^{38}(2014)$ & $88 \mathrm{~N}$ & $2,000,000$ & $4 \mathrm{~Hz}$ & - & - & - \\
\hline Tey and Lui ${ }^{42}(2014)$ & - & - & - & $5^{\circ} \mathrm{C}$ to $55^{\circ} \mathrm{C}$ & $30 \mathrm{~s}$ & 500 \\
\hline Wandscher et al. ${ }^{44}$ (2014) & $130 \mathrm{~N}$ & $1,500,000$ & $2.2 \mathrm{~Hz}$ & - & - & - \\
\hline Aggarwal et al. ${ }^{45}$ (2013) & - & - & - & $5^{\circ} \mathrm{C}$ to $55^{\circ} \mathrm{C}$ & $n r$ & 5,000 \\
\hline Ambica et al. ${ }^{46}(2013)$ & $49 N$ & $1,200,000$ & $1.3 \mathrm{~Hz}$ & $5^{\circ} \mathrm{C}$ to $55^{\circ} \mathrm{C}$ & $30 \mathrm{~s}$ & 5,000 \\
\hline Barcellos et al. ${ }^{49}$ (2013) & $30 \mathrm{~N}$ & 250,000 & $2.6 \mathrm{~Hz}$ & - & - & - \\
\hline Hou et al. ${ }^{52}(2013)$ & $50 \mathrm{~N}$ & 300,000 & $2 \mathrm{~Hz}$ & - & - & - \\
\hline Mobilio et al. ${ }^{56}(2013)$ & $10 \mathrm{~N}$ to $100 \mathrm{~N}$ & 1,500 & $4 \mathrm{~mm} / \mathrm{min}$ & $5^{\circ} \mathrm{C}$ to $60^{\circ} \mathrm{C}$ & 20 & 1,500 \\
\hline Naumann et al. ${ }^{57}$ (2013) & $50 \mathrm{~N}$ & $1,200,000$ & $n r$ & $5^{\circ} \mathrm{C}$ to $55^{\circ} \mathrm{C}$ & $120 \mathrm{~s}$ & 3,000 \\
\hline Ozcan and Sahin ${ }^{58}$ (2013) & - & - & - & $5^{\circ} \mathrm{C}$ to $55^{\circ} \mathrm{C}$ & $20 \mathrm{~s}$ & 6,000 \\
\hline Samran et al. ${ }^{60}(2013)$ & $50 \mathrm{~N}$ & $1,200,000$ & $1.2 \mathrm{~Hz}$ & $5^{\circ} \mathrm{C}$ to $55^{\circ} \mathrm{C}$ & $30 \mathrm{~s}$ & 6,499 \\
\hline Zicari et al. ${ }^{62}$ (2013) & $50 \mathrm{~N}$ & $1,200,000$ & $1.6 \mathrm{~Hz}$ & - & - & - \\
\hline Aggarwal et al. ${ }^{63}$ (2012) & $60 \mathrm{~N}$ & 150,000 & $5 \mathrm{~Hz}$ & - & - & - \\
\hline Akman et al. ${ }^{64}$ (2012) & - & - & - & $5^{\circ} \mathrm{C}$ to $55^{\circ} \mathrm{C}$ & $10 \mathrm{~s}$ & 5,000 \\
\hline Borelli et al. ${ }^{66}(2012)$ & - & - & - & $5^{\circ} \mathrm{C}$ to $60^{\circ} \mathrm{C}$ & $20 \mathrm{~s}$ & 1,500 \\
\hline Costa et al. ${ }^{68}(2012)$ & $30 \mathrm{~N}$ & 250,000 & $2 \mathrm{~Hz}$ & - & - & - \\
\hline Nie et al. ${ }^{76}(2012)$ & $127.4 \mathrm{~N}$ & $1,200,000$ & $6 \mathrm{~Hz}$ & - & - & - \\
\hline Rosa et al..$^{77}$ (2012) & $90 \mathrm{~N}$ & $1,000,000$ & $4 \mathrm{~Hz}$ & - & - & - \\
\hline Sterzenbach et al. ${ }^{80}$ (2012) & $49 N$ & $1,200,000$ & $n r$ & $5^{\circ} \mathrm{C}$ to $55^{\circ} \mathrm{C}$ & $120 s$ & 6,000 \\
\hline Tunjan et al..$^{81}$ (2012) & $50 \mathrm{~N}$ & $1,200,000$ & $1.6 \mathrm{~Hz}$ & $5^{\circ} \mathrm{C}$ to $55^{\circ} \mathrm{C}$ & $120 s$ & 3,000 \\
\hline Zicari et al. ${ }^{82}$ (2012) & $50 \mathrm{~N}$ & $1,200,000$ & $1.6 \mathrm{~Hz}$ & - & - & - \\
\hline Kathuria et al. ${ }^{85}$ (2011) & - & - & - & $5^{\circ} \mathrm{C}$ to $55^{\circ} \mathrm{C}$ & $30 \mathrm{~s}$ & 5,000 \\
\hline Khatter et al. ${ }^{86}$ (2011) & - & - & - & $5^{\circ} \mathrm{C}$ to $55^{\circ} \mathrm{C}$ & $30 \mathrm{~s}$ & 10,000 \\
\hline Li et al. ${ }^{87}(2011)$ & $49 N$ & 60,000 & $1.7 \mathrm{~Hz}$ & $5^{\circ} \mathrm{C}$ to $50^{\circ} \mathrm{C}$ & $70 \mathrm{~s}$ & 12,000 \\
\hline Mangold and Kern ${ }^{89}$ (2011) & $45 \mathrm{~N}$ & $1,200,000$ & $1.2 \mathrm{~Hz}$ & $5^{\circ} \mathrm{C}$ to $55^{\circ} \mathrm{C}$ & $30 \mathrm{~s}$ & 6,499 \\
\hline Naumann et al. ${ }^{90}(2011)$ & $50 \mathrm{~N}$ & $1,200,000$ & $n r$ & $5^{\circ} \mathrm{C}$ to $55^{\circ} \mathrm{C}$ & $120 s$ & 6,000 \\
\hline Ni et al. ${ }^{91}(2011)$ & $10 \mathrm{~N} \mathrm{~N}$ to $100 \mathrm{~N}$ & 3,000 & $4 \mathrm{~mm} / \mathrm{min}$ & $5^{\circ} \mathrm{C}$ to $60^{\circ} \mathrm{C}$ & $60 \mathrm{~s}$ & 3,000 \\
\hline Nothdurft et al..$^{92}(2011)$ & $50 \mathrm{~N}$ & $1,200,000$ & $n r$ & $5^{\circ} \mathrm{C}$ to $55^{\circ} \mathrm{C}$ & $n r$ & 10,000 \\
\hline Santini et al. ${ }^{94}$ (2011) & $50 \mathrm{~N}$ & $1,000,000$ & $1 \mathrm{~Hz}$ & - & - & - \\
\hline Sherfudhin et al..$^{95}$ (2011) & $50 \mathrm{~N}$ to $200 \mathrm{~N}$ & 15,000 & $2 \mathrm{~Hz}$ & - & - & - \\
\hline Silva et al. ${ }^{96}(2011)$ & $50 \mathrm{~N}$ & 300,000 & $n r$ & - & - & - \\
\hline Chuang et al. ${ }^{98}(2010)$ & - & - & - & $5^{\circ} \mathrm{C}$ to $60^{\circ} \mathrm{C}$ & $20 s$ & 1,500 \\
\hline
\end{tabular}




\section{Monotonic loading}

Most of the included studies employed monotonic loading $(51.1 \%)$ to evaluate the fracture strength of endodontically treated teeth restored with post and core material, which is in agreement with the review of Naumann et al. ${ }^{6}$ (2009). A monotonic test involves the application of a static load until the specimen fractures. This kind of test is usually the first step in the evaluation of biomaterials and it is commonly used in order to obtain basic knowledge regarding the fracture behavior and capacity of resisting fracture. Results obtained from monotonic tests must be evaluated with caution with regards to the prediction of the clinical behavior. In many cases, failure loads far exceed reported ranges for mastication, swallowing and bruxism ${ }^{109}$.

Masticatory loads are often quoted as ranging between $20 \mathrm{~N}$ and $250 \mathrm{~N}^{110}$. The average applied load in bruxism was found to be $423 \mathrm{~N}$, with a peak load of $800 \mathrm{~N}^{111}$. There are in vitro studies reporting loads to fracture of $1021 \mathrm{~N}$ for premolars ${ }^{33}$ and $1406 \mathrm{~N}$ for central incisors ${ }^{42}$ restored with glass fiber posts and metal crowns, values that far exceed the normal masticatory loads.

\section{Cyclic loading}

Cyclic loading was used in just $38 \%$ of the studies and it involves the application of a minimum and a maximum stress, often with constant amplitude and a sinusoidal wave mode. This type of loading may be used to estimate the survival probability of a treatment ${ }^{15,44}$; to evaluate the fatigue strength $^{112}$; and to promote aging, all of which try to simulate the oral environment.

The term 'fatigue' is used to define the failure of a material subjected to stress or strain over a period of time. Failure may manifest itself as fracture, loss of compliance, or wear, and it is often influenced by environmental factors ${ }^{113}$. Considering that dental materials are exposed to chemical and loading challenges, it is easy to understand why restorative procedures usually fail due to fatigue.

One methodology that considers the fatigue failure of restorative treatments in endodontically treated teeth consists in applying a fixed stress on the specimen, and evaluating the number of cycles required for failure. The data are then subjected to a survival analysis, such as the Kaplan Meier test, which for instance it may express the probability of specimens surpass a period of time without the occurrence failure. Wandscher et al. ${ }^{44}$ (2014) employed this methodology to evaluate the survival rate of weakened and non-weakened bovine roots restored with different intracanal posts. Specimens were mechanically cycled $(130 \mathrm{~N}, 2.2 \mathrm{~Hz}$ and 1.5 million cycles) and were evaluated after each $5 \mathrm{x}$ $10^{4}$ cycles to determine the presence of cracks as a primary outcome (event).
Another method that allows for the estimation of survival is the 'step-test'. This method consists in submitting a specimen to increasing load, over a fixed number of cycles, until failure ${ }^{114}$. Data of survival percentage $v s$. load levels are then plotted on a graph and a log-rank test is normally used to compare the groups. Güth et al. ${ }^{15}$ (2016) used this methodology to investigate the restoration of broken-down endodontically treated molars without ferrule effect using glass ceramic crowns on different composite resin core buildups. A cyclic load was applied at a frequency of $5 \mathrm{~Hz}$, starting with a load of $200 \mathrm{~N}$ for 5000 cycles, followed by stages of 400 , $600,800,1000,1200$ and $1400 \mathrm{~N}$ at a maximum of 30,000 cycles each. Samples were loaded until fracture or to a maximum of 185,000 cycles. The number of endured cycles was recorded. The survival probability at each load interval was calculated based on the number of specimens that started the interval intact and the number of specimens that fractured during that interval. The comparison among the groups was performed using a log-rank test. This methodology may be considered an accelerated fatigue test, remaining at an intermediate level between the monotonic tests (employ very high single load until failure, not clinically relevant) and traditional cyclic fatigue tests (employ low loads and a high number of cycles, which is time-consuming) ${ }^{115}$.

A very useful testing method for determining the mean fatigue strength at any specified life is the up-and-down method, also called the 'staircase' method. The term 'fatigue strength' identifies the maximum stress level that the material can support without failure at a specified lifetime. The term 'fatigue limit' represents the stress below which the material supports an infinite number of cycles without failure ${ }^{114}$. To perform an up-and-down test, the number of cycles is previously set. The first specimen tested is loaded with a stress lower than the maximum stress supported by the material in a corresponding monotonic test. If the specimen fails before reaching the desired lifespan, the stress level is decreased by a preselected increment and the second specimen is tested at a new lower stress level. If the first specimen reaches the desired lifespan, the stress level is increased by the preselected increment and the second specimen is tested at this new higher stress level. The test is continued in this manner, with each succeeding specimen being tested at a stress level that is one increment above or below its predecessor, depending on whether the predecessor succeeded or failed. Fifteen to thirty specimens are required to adequately perform the test. When the test is completed, mathematical expressions, based on the less frequent event (success or failure), are used to calculate the mean fatigue strength and the standard deviation at the prescribed life $\mathrm{e}^{114,116}$.

The staircase approach was used in the study of Wiskott et al. ${ }^{112}$ (2007) which aimed to closely du- 
plicate intraoral loading conditions in a laboratory test designed to compare the resistance to fatigue loading of different endodontic post/natural root combinations. The repetitive, alternating and multivectorial intraoral force patterns were reproduced by subjecting the specimens to a rotating cantilever beam test. The number of cycles was set at 1 million, and a force increment of $2.5 \mathrm{~N}$ was used. The fatigue strength values obtained for each group investigated were compared calculating the 95\% confidence intervals. Means with overlapping intervals were considered equivalent ${ }^{114,116}$.

In addition of being used for survival analysis and fatigue strength tests, cyclic loading has been used to promote the aging of the specimens before a monotonic test. In the present review, 36.6\% articles used mechanical cycling for this purpose. Mechanical cycling can reproduce the pattern of a chewing load, which consists of high numbers of low cyclic loads, promoting damage accumulation over the time, which is not seen during single-load failure testing ${ }^{114}$. With regards to the load used for aging, some authors ${ }^{118}$ recommended that the fatigue load must be lower than the material's monotonic fracture load. Alternatively, the maximum masticatory force in canines and premolars in healthy men is typically $190 \mathrm{~N}$ and $254 \mathrm{~N}$, respectively, and $119 \mathrm{~N}$ and $178 \mathrm{~N}$, respectively, in women ${ }^{119}$. Thus, care should be taken to not exceed the load limit of the maximum bite force of humans, which would not be adequate for aging, since this load must be constant and low.

Great variability in the mechanical cycling parameters, to include the number of cycles, frequency and applied load, can be observed in Table 3.

According to Wiskott et al. ${ }^{120}$ (1995) cyclic tests for simulating the oral environment should be performed with at least 1 million cycles. To reach this number, those authors assumed 3 periods of $15 \mathrm{mi}$ nutes of chewing per day, at a chewing rate of 60 cycles per minute $(1 \mathrm{~Hz})$, resulting in 2,700 chewing cycles per day and 1 million cycles per year.

In the articles included in this review, the maximum number of cycles used to promote aging was 2 million, ${ }^{38}$ which represents, according to Wiskott et al. ${ }^{120}$ (1995), just two years of function. The use of low frequencies (number of load cycles per second), usually ranging from $1 \mathrm{~Hz}$ to $2 \mathrm{~Hz}$, to simulate the frequency of chewing activity ${ }^{121}$, may discourage many researchers to carry out studies with a higher number of cycles. Six days would be necessary to conclude a mechanical cycling for 1 million cycles using frequency of $2 \mathrm{~Hz}$. If a higher frequency is applied, such as $20 \mathrm{~Hz}$, this time would be reduced to 14 hours, optimizing data collection. Thus, the effect of the load frequency in the cyclic fatigue behavior of restorative materials is still not completely understood, which is a relevant subject that deserves attention in the future.

\section{Thermocycling}

Thermocycling consists of a sequence of thermal stressing in which the sample is moved between high and low temperature environments for a predetermined number of cycles ${ }^{122}$. This test is conventionally used to simulate the thermal changes and water exposure that may occur in the oral cavity during eating, drinking, or even breathing ${ }^{123}$, and it is an appropriate method for testing thermal stability of a dental material. Hence, specimens subjected to thermocycling tend to give more meaningful results.

Thermocycling was performed in $27.2 \%$ of the studies, followed by mechanical cycling or not. The temperature regimen most used was $5^{\circ} \mathrm{C}$ to $55^{\circ} \mathrm{C}$, following the recommendations of ISO TR $11405: 1994^{124}$, and the most frequent dwell time was 30 seconds. The studies differed with respect to the number of cycles employed (minimum 500 cycles; maximum 12,000 cycles) (Table 3 ).

Aiming test standardization, and considering that a specific regimen does not represent the natural in vivo variability, Gale and Darvell ${ }^{123}$ (1999) proposed a thermocycling regimen of $35^{\circ} \mathrm{C}(28 \mathrm{~s})$, $15^{\circ} \mathrm{C}(2 \mathrm{~s}), 35^{\circ} \mathrm{C}(28 \mathrm{~s}), 45^{\circ} \mathrm{C}(2 \mathrm{~s})$, which would be clinically relevant. When considering the number of cycles, it was proposed that 10,000 cycles might represent one service year, considering that cycles might occur between 20 and 50 times in a day.

\section{Load application in the fracture tests}

In most of the studies, the load was applied at an angle of $45^{\circ}$ in relation to the long axis of the tooth. This angle is usually chosen to simulate the average interincisal angle between maxillary and mandibular incisors in normal class I occlusion ${ }^{125}$. The site of load application changed according to the type of tooth. Hence, for incisors and canines, the load was generally applied on the palatal surface, $2-4 \mathrm{~mm}$ below the incisal edge. For pre-molars and molars, the load was usually applied on the occlusal surface.

González-Lluch et al. ${ }^{126}$ (2012) investigated the effect of different test parameters on the mechanical strength of endodontically treated teeth restored with posts and cores using a validated 3D biomechanical model and sensitivity analysis. The results pointed up the remarkable importance of the loading angle on the final restoration strength. A better mechanical performance was observed for compressive loads $\left(25^{\circ}\right.$ and $\left.0^{\circ}\right)$, while a lower resistance was reported when the flexion component of the load increased $\left(75^{\circ}\right.$ and $\left.90^{\circ}\right)$. Therefore, flexural loads seem to be more critical than compressive loads regarding the mechanical strength of endodontically treated teeth restored with posts and cores. 
The shape and the diameter of the load application device define the contact with the tooth and the restorative material. Silva et al. ${ }^{127}$ (2012) evaluated the effect of different load application devices (sphere with 2 and $6 \mathrm{~mm}$ of diameter; cylinder with 2 and $6 \mathrm{~mm}$ of diameter; wedge shaped device; individualized metallic antagonist tooth) on fracture resistance and failure mode of maxillary premolars restored with composite resin. They concluded that the load application device influences significantly the fracture strength and failure mode of the teeth-restoration complex.

Most part of the studies included in this review employed spherical- and cylinder- shaped indenters with diameters ranging from $1 \mathrm{~mm}$ to $6 \mathrm{~mm}$, besides the edge shaped tips and individualized antagonist. However, around $40 \%$ of the included studies, did not reported any information about the shape and the dimensions of the devise used to apply the load.

According to Kelly 117 (1999), steel indenter balls would have diameters between $40 \mathrm{~mm}$ and $1 \mathrm{~m}$ to develop clinically realistic contacts. This dimension was calculated considering simple circular contact of 0.5-3 mm diameter between two facets, load ranges of $100 \mathrm{~N}$ to $700 \mathrm{~N}$, and contact pressures of 5 $\mathrm{MPa}$ to $890 \mathrm{MPa}$. Tooth-to-tooth contacts do not appear to be well represented by small steel balls, since those spherical indenters may cause failures that are not seen clinically. Therefore, in order to simulate clinical contact pressures, the use of indenter balls with a greater diameter should be considered.

One possible limitation of the present study relates to the literature research, in which a filter for publications date was set to return studies from the last five years, due the great number of articles published regarding the mechanical behavior of teeth restored with post and core. Therefore, the results obtained in the present study represent the actual scenario of the research in this area. Besides, the searched literature was conducted only in the PubMed/MEDLINE database. However, although conducting a search of EMBASE can result in a wider range of literature, it also results in a higher number of false positives in the form of unnecessarily identified studies. ${ }^{128}$ Thus, PubMed/MEDLINE seemed to be a suitable option for reviews in the biomedical area. ${ }^{129}$

Another limitation of this study is that the mode of failure obtained in the included in vitro studies was not compared to the mode of failure that occurs clinically. Many variables may influence the mode of failure of endodontically treated teeth restored with post and core, such as elasticity modulus ${ }^{130}$, diameter ${ }^{41,42}$ and length of the post ${ }^{71,82}$, and ferrule effect. ${ }^{27}$ These variables must be taken into account when comparing in vitro and clinical studies to avoid misleading conclusions. The authors suggest that a future review should be designed to properly compare the mode of failure obtained in laboratory and in clinical studies for endodontically treated teeth restored with different post/core systems.

\section{Conclusions}

Regarding sample preparation, upper central incisors were used most frequently; the natural mobility of teeth was simulated using an artificial periodontal ligament in $66.7 \%$ of the studies; and a crown was placed in 59\% of the studies. Monotonic loading tests are still prevalent (51.1\%). New test methodologies, applying cyclic loads, have been employed to evaluate the fatigue strength of teeth restored with posts and cores, such as step-test and staircase approach. However, the methodology employed in most of the in vitro studies did not reproduce the clinical challenges that the endodontically treated teeth restored with post and core are submitted in mouth, such as cyclic loading, $\mathrm{pH}$ and temperature variations and humidity. Therefore, the extrapolation of the in vitro results to the clinical practice should be made carefully.

Considering future publications, the authors claim that more details should be given in the description of the fracture strength tests, since many articles do not show enough information regarding the shape and dimension of the device used for load applications.

It is still important to highlight the heterogeneity among the studies, which require caution when trying to compare the results of different studies in the literature.

\section{Resumo}

Objetivo: avaliar criticamente os métodos in vitro utilizados para avaliar o comportamento mecânico de dentes tratados endodonticamente, restaurados com pino intra-radicular e núcleo. Revisão de literatura: uma busca por estudos in vitro foi conduzida na base de dados PubMed, utilizando-se os termos: ("endodontic"* OU "intracanal post") E ("fracture" OU "resistance" OU "load" OU "strength"). Durante a busca, utilizou-se um filtro para a seleção de publicações do período compreendido entre outubro de 2010 a outubro de 2015. A estratégia de busca resultou em 1556 artigos. Após a análise dos critérios de elegibilidade, 92 artigos foram incluídos em uma análise descritiva. Incisivos centrais superiores foram os dentes mais frequentemente utilizados nos estudos. A mobilidade natural dos dentes foi simulada por meio de ligamento periodontal em $66,7 \%$ dos artigos incluídos. Em 32,2\% dos estudos, a carga para fratura foi aplicada diretamente no núcleo. Ciclagem térmica foi realizada em $27,2 \%$ dos artigos, enquanto que carregamento cíclico foi utilizado em apenas 38\% dos estudos. Considerações finais: simulação do ligamento periodontal, ciclagem térmica e carregamento cíclico são alguns dos métodos utilizados para tentar aproximar os estudos laboratoriais das condições clínicas a que dentes restaurados com retentores intra-radiculares e núcleos são submetidos. Novos tipos de 
ensaio, como step-test e staircase têm sido empregados para avaliar o comportamento à fadiga desses sistemas. Entretanto, cabe salientar que, considerando-se o contexto no qual a maioria dos estudos foi conduzida, a extrapolação dos resultados para a prática clínica deve ser realizada com muita cautela.

Palavras-chave: Fadiga. Técnicas In Vitro. Dente Não Vital. Técnica para Retentor Intra-radicular.

\section{References}

1. Aurélio IL, Fraga S, Rippe MP, Valandro LF. Are posts necessary for the restoration of root filled teeth with limited tissue loss? A structured review of laboratory and clinical studies. Int Endod J. Forthcoming 2015 Sep 1. Doi: 10.1111/ iej.12538.

2. Kelly JR, Benetti P, Rungruanganunt P, Bona A Della. The slippery slope - Critical perspectives on in vitro research methodologies. Dent Mater. 2012;28(1):41-51.

3. Roulet JF. Is in vitro research in restorative dentistry useless? J Adhes Dent. 2012;14:103-4.

4. Kelly JR. Evidence-based decision making: Guide to reading the dental materials literature. J Prosthet Dent. 2006;95(2):152-60.

5. Morgano S, Rodrigues A, CE S. Restoration of endodontically treated teeth. Dent Clin North Am. 2004;48:397-416.

6. Naumann M, Metzdorf G, Fokkinga W, Watzke R, Sterzenbach G, Bayne S, et al. Influence of test parameters on in vitro fracture resistance of post-endodontic restorations: A structured review. J Oral Rehabil. 2009;36(4):299-312.

7. Moher D, Liberati A, Tetzlaff J, Altman DG. Academia and Clinic Annals of Internal Medicine Preferred Reporting Items for Systematic Reviews and Meta-Analyses : Annu Intern Med. 2009;151(4):264-9.

8. Amarnath GS, Swetha MU, Muddugangadhar BC, Sonika R, Garg A, Rao TRP. Effect of post material and length on fracture resistance of endodontically treated premolars: an in-vitro study. J Int oral Heal. 2015;7(7):22-8.

9. Bilgin MS, Erdem A, Dilber E, Ersoy I. Comparison of fracture resistance between cast, $\mathrm{CAD} / \mathrm{CAM}$ milling, and direct metal laser sintering metal post systems. J Prosthodont Res. 2016; 60(1):23-8.

10. Bitter K, Schubert A, Neumann K, Blunck U, Sterzenbach G, Rüttermann S. Are self-adhesive resin cements suitable as core build-up materials? Analyses of maximum load capability, margin integrity, and physical properties. Clin Oral Investig. Forthcoming 2015 Oct 8.

11. Broch J, Marchionatti A, Bergoli C, Valandro L, Kaizer O. Fracture resistance of weakened roots restored with different intracanal retainers. Gen Dent. 2015;63(June):58-63.

12. Dastjerdi MR, Chaijan KA, Tavanafar S. Fracture resistance of upper central incisors restored with different posts and cores. Restor Dent Endod. 2015;40:229-35.

13. Farina AP, Weber AL, Severo B de P, Souza MA, Cecchin D. Effect of length post and remaining root tissue on fracture resistance of fibre posts relined with resin composite. J Oral Rehabil. 2015;42(3):202-8.

14. Gaikwad A, Pal KS, Ranganath LM, Jain JK, Patil P, Babar G. Fracture Resistance of Teeth Restored with Various Post Designs and Cemented with Different Cements : An In-vitro Study. J Int Oral Heal. 2015;7(April):33-7.
15. Güth JF, Edelhoff D, Goldberg J, Magne P. CAD/CAM polymer vs direct composite resin core buildups for endodontically treated molars without ferrule. Oper Dent. 2016; 41(1):53-63.

16. Khaledi AA, Sheykhian S, Khodaei A. Evaluation of retention of two different cast post-core systems and fracture resistance of the restored teeth. J Dent ( $\mathrm{Sh} \square \mathbf{r} \square \mathbf{z}$, Iran). 2015;16(2):121-8.

17. Kumar L, Pal B, Pujari P. An assessment of fracture resistance of three composite resin core build-up materials on three prefabricated non-metallic posts, cemented in endodontically treated teeth: an in vitro study. PeerJ. 2015;3:e795.

18. Kurthukoti A, Paul J, Gandhi K, Rao DJ. Fracture resistance of endodontically treated permanent anterior teeth restored with three different esthetic post systems: An in vitro study. J Indian Soc Pedod Prev Dent. 2015;33(4):296.

19. Maroulakos G, Nagy WW, Kontogiorgos ED. Fracture resistance of compromised endodontically treated teeth restored with bonded post and cores: An in vitro study. J Prosthet Dent [Internet]. 2015;114(3):1-8.

20. Muangamphan P, Sattapan B, Kukiattrakoon B, Thammsitboon K. The effect of incomplete crown ferrules on fracture resistance and failure modes of endodontically treated maxillary incisors restored with quartz fiber post, composite core, and crowns. J Conserv Dent. 2015;18(3):187.

21. Samran A, Al-Afandi M, Kadour JA, Kern M. Effect of ferrule location on the fracture resistance of crowned mandibular premolars: An invitro study. J Prosthet Dent. 2015;114(1):86-91.

22. Schmidlin PR, Stawarczyk B, De Abreu D, Bindl A, Ender A. Fracture resistance of endodontically treated teeth without ferrule using a novel $\mathrm{H}$-shaped short post. Quintessence Internaltional. 2015;46(2):97-109.

23. Sonkesriya S, Olekar ST, Saravanan V, Singh Chauhan R, Rampratap Chaurasia V. An in vitro comparative evaluation of fracture resistance of custom made, metal, glass fiber reinforced and carbon reinforced posts in endodontically treated teeth. J Int Oral Heal. 2015;7(5):53-5.

24. Sreedevi S, Sanjeev R, Raghavan R, Abraham A, Rajamani T, Govind GK. an in vitro study on the effects of post-core design and ferrule on the fracture resistance of endodontically treated maxillary central incisors. J Int Oral Heal. 2015;7(8):37-41.

25. Vachhani KA, Asnani MM. Eevaluation of fracture strength of teeth restored with different types of posts luted with different luting cements: An in vitro study. Niger J Clin Pract. 2015;18(3):411-5.

26. Zhang YY, Peng MD, Wang YN, Li Q. The effects of ferrule configuration on the anti-fracture ability of fiber post-restored teeth. J Dent. 2015;43(1):117-25.

27. Abdulrazzak SS, Sulaiman E, Atiya BK, Jamaludin M. Effect of ferrule height and glass fibre post length on fracture resistance and failure mode of endodontically treated teeth. Aust Endod J. 2014;40(2):81-6.

28. Aggarwal V, Singla M, Yadav S, Yadav H, Sharma V, Bhasin SS. The effect of ferrule presence and type of dowel on fracture resistance of endodontically treated teeth restored with metal-ceramic crowns. J Conserv Dent. 2014;17(2):183-7.

29. Alharbi FA, Nathanson D, Morgano SM, Baba NZ. Fracture resistance and failure mode of fatigued endodontically treated teeth restored with fiber-reinforced resin posts and metallic posts in vitro. Dent Traumatol. 2014;30(4):317-25. 
30. Amin RA, Mandour MH, Abd El-Ghany OS. Fracture strength and nanoleakage of weakened roots reconstructed using relined glass fiber-reinforced dowels combined with a novel prefabricated core system. J Prosthodont. 2014;23(6):484-94.

31. Chieruzzi M, Rallini M, Pagano S, Eramo S, D’Errico P, Torre $\mathrm{L}$, et al. Mechanical effect of static loading on endodontically treated teeth restored with fiber-reinforced posts. J Biomed Mater Res - Part B Appl Biomater. 2014;102(2):384-94.

32. Franco EB, Valle Al, Almeida ALPF, Rubo JH, Pereira JR. Fracture resistance of endodontically treated teeth restored with glass fiber posts of different lengths. J Prosthet Dent. 2014;111(1):30-4.

33. Furuya Y, Huang S-H, Takeda Y, Fok A, Hayashi M. Fracture strength and stress distributions of pulpless premolars restored with fiber posts. Dent Mater J. 2014;33(6):852-8.

34. Gomes GM, Gomes OM, Gomes JC, Loguercio AD, Calixto $\mathrm{AL}$, Reis A. evaluation of different restorative techniques for filling flared root canals: fracture resistance and bond strength after mechanical fatigue. J Adhes Dent. 2014;16(3).

35. Krastl G, Izquierdo A, B??ttel L, Zitzmann NU, Schmitter $\mathrm{M}$, Weiger R. Does an intracanal composite anchorage replace posts? Clin Oral Investig. 2014;18(1):147-53.

36. Pereira JR, Valle AL, Shiratori FK, Ghizoni JS, Bonfante EA. The effect of post material on the characteristic strength of fatigued endodontically treated teeth. J Prosthet Dent. 2014;112(5):1225-30.

37. Ramírez-Sebastià A, Bortolotto T, Cattani-Lorente M, Giner L, Roig M, Krejci I. Adhesive restoration of anterior endodontically treated teeth: Influence of post length on fracture strength. Clin Oral Investig. 2014;18(2):545-54.

38. Rippe MP, Santini MF, Bier CAS, Baldissara P, Valandro LF. Effect of root canal preparation, type of endodontic post and mechanical cycling on root fracture strength. J Appl Oral Sci. 2014;22(3):165-73.

39. Santos-Filho PCF, Veríssimo C, Soares PV, Saltarelo RC, Soares CJ, Marcondes Martins LR. Influence of ferrule, post system, and length on biomechanical behavior of endodontically treated anterior teeth. J Endod. 2014;40(1):119-23.

40. Thareja P, Singh S. Fracture resistance of endodontically treated maxillary central incisors with varying ferrule heights and configurations: In vitro study. J Conserv Dent. 2014;17(2):115.

41. Soundar SIJ, Suneetha TJ, Angelo MC, Kovoor LC. Analysis of fracture resistance of endodontically treated teeth restored with different post and core system of variable diameters: An in vitro study. J Indian Prosthodont Soc. 2014;14(2):144-50.

42. Tey KC, Lui JL. The effect of glass fiber-reinforced epoxy resin dowel diameter on the fracture resistance of endodontically treated teeth. J Prosthodont. 2014;23(7):572-81.

43. Veríssimo C, Simamoto Júnior PC, Soares CJ, Noritomi PY, Santos-Filho PCF. Effect of the crown, post, and remaining coronal dentin on the biomechanical behavior of endodontically treated maxillary central incisors. J Prosthet Dent. 2014;111(3):234-46.

44. Wandscher VF, Bergoli CD, Limberger IF, Ardenghi TM, Valandro LF. Preliminary results of the survival and fracture load of roots restored with intracanal posts: weakened vs nonweakened roots. Oper Dent. 2014;541-55.

45. Aggarwal R, Gupta S, Tandan A, Gupta NK, Dwivedi R, Aggarwal R. Comparative evaluation of fracture resistance of various post systems using different luting agents under tangential loading. J oral Biol craniofacial Res. Elsevier; 2013;3(2):63-7.
46. Ambica K, Mahendran K, Talwar S, Verma M, Padmini G, Periasamy R. Comparative evaluation of fracture resistance under static and fatigue loading of endodontically treated teeth restored with carbon fiber posts, glass fiber posts, and an experimental dentin post system: An in vitro study. $J$ Endod. 2013;39(1):96-100.

47. Bacchi A, Dos Santos MBF, Pimentel MJ, Caetano CR, Sinhoreti MAC, Consani RLX. Influence of post-thickness and material on the fracture strength of teeth with reduced coronal structure. J Conserv Dent. 2013;16(2):139-43.

48. Balkaya MC, Birdal IS. Effect of resin-based materials on fracture resistance of endodontically treated thin-walled teeth. J Prosthet Dent. 2013;109(5):296-303.

49. Barcellos RR, Correia DPD, Farina AP, Mesquita MF, Ferraz CCR, Cecchin D. Fracture resistance of endodontically treated teeth restored with intra-radicular post: The effects of post system and dentine thickness. J Biomech. 2013;46(15):2572-7.

50. Carlini-Júnior B, Cecchin D, Farina A, Pereira G, Prieto L, Paulillo L. Influence of remaining coronal structure and of the marginal design on the fracture strength of roots restored with cast post and core. Acta Odontol Scand. 2013;71:278-82.

51. Evangelinaki E, Tortopidis D, Kontonasaki E, Fragou T, Gogos C, Koidis P. Effect of a crown ferrule on the fracture strength of endodontically treated canines restored with fiber posts and metal-ceramic or all-ceramic crowns. Int $\mathrm{J}$ Prosthodont. 2013;26(4):384-7.

52. Hou QQ, Gao YM, Sun L. Influence of fiber posts on the fracture resistance of endodontically treated premolars with different dental defects. Int J Oral Sci. 2013;5(3):167-71.

53. Jiangkongkho P, Kamonkhantikul K, Takahashi H, Arksornnukit M. Fracture resistance of endodontically treated teeth using fiber post with an elastic modulus similar to dentin. Dent Mater J. 2013;32(5):781-6.

54. Jindal S, Jindal R, Gupta K, Mahajan S, Garg S. Comparative evaluation of the reinforcing effect of different post systems in the restoration of endodontically treated human anterior teeth at two different lengths of post space preparation- an in vitro study. J Dent (Tehran). 2013;10(2):124-33.

55. Kaya BM, Ergun G. The effect of post length and core material on root fracture with respect to different post materials. Acta Odontol Scand. 2013;71(5):1063-70.

56. Mobilio N, Borelli B, Sorrentino R, Catapano S. Effect of fiber post length and bone level on the fracture resistance of endodontically treated teeth. Dent Mater J. 2013;32(5):816-21.

57. Naumann M, Hohmann C, Happe A, Beuer F, Frankenberger R, Seemann R, et al. Are implants more reliable than severely compromised endodontically treated teeth as abutments for zirconia-based FPDs?: In vitro results of long-term preclinical load simulation. Clin Oral Investig. 2013;17(7):1685-92.

58. Ozcan N, Sahin E. In vitro evaluation of the fracture strength of all-ceramic core materials on zirconium posts. Eur J Dent. 2013;7(4):455-60.

59. Rippe MP, Santini MF, Souza CA, Luiz A, Borges S, Valandro LF. Root Canal Filling : Fracture Strength of Roots and Finite Element Analysis. 2013;24:619-25.

60. Samran A, El Bahra S, Kern M. The influence of substance loss and ferrule height on the fracture resistance of endodontically treated premolars. An in vitro study. Dent Mater. 2013;29(12):1280-6. 
61. Torres-Sánchez C, Montoya-Salazar V, Córdoba P, Vélez C, Guzmán-Duran A, Gutierrez-Pérez JL, et al. Fracture resistance of endodontically treated teeth restored with glass fiber reinforced posts and cast gold post and cores cemented with three cements. J Prosthet Dent. 2013;110(2):127-33.

62. Zicari F, Van Meerbeek B, Scotti R, Naert I. Effect of ferrule and post placement on fracture resistance of endodontically treated teeth after fatigue loading. J Dent. 2013;41(3):207-15.

63. Aggarwal V, Singla M, Miglani S, Kohli S. Comparative Evaluation of Fracture Resistance of Structurally Compromised Canals Restored with Different Dowel Methods. J Prosthodont. 2012;21(4):312-6.

64. Akman S, Akman M, Eskitaşcioğlu G, Belli S. The use of endodontically treated and/or fiber post-retained teeth as abutments for fixed partial dentures. Clin Oral Investig. 2012;16(5):1485-91.

65. Biacchi G, Basting R. Comparison of fracture strength of endocrowns and glass fiber post-retained conventional crowns. Oper Dent. 2012;37(2):130-6.

66. Borelli B, Sorrentino R, Zanore F, Ferrari M. Effect of the length of glass fiber posts on the fracture resistance of restored maxillary central incisors. Am J Dent. 2012;25:79-83.

67. Castro CG, Santana FR, Roscoe MG, Simamoto PC, Santos-Filho PCF, Soares CJ. Fracture resistance and mode of failure of various types of root filled teeth. Int Endod J. 2012;45(9):840-7.

68. Costa R, Morais E, Campos E, Michel M, Gonzaga C, Correr G. Customized fiber glass posts. Fatigue and fracture resistance. Am J Dent. 2012;25:35-8.

69. Fragou T, Tortopidis D, Kontonasaki E, Evangelinaki E, Ioannidis K, Petridis $\mathrm{H}$, et al. The effect of ferrule on the fracture mode of endodontically treated canines restored with fibre posts and metal-ceramic or all-ceramic crowns. J Dent. 2012;40(4):276-85.

70. Hedge J, Ramakrishna, Bashetty K, Srirekha, Lekha, Champa. An in vitro evaluation of fracture strength of endodontically treated teeth with simulated flared root canals restored with different post and core systems. J Conserv Dent. 2012;15:223-7.

71. Jindal S, Jindal R, Mahajan S, Dua R, Jain N, Sharma S. In vitro evaluation of the effect of post system and length on the fracture resistance of endodontically treated human anterior teeth. Clin Oral Investig. 2012;16(6):1627-33.

72. Kaur J, Sharma N, Singh H. In vitro evaluation of glass fiber post. J Clin Exp Dent. 2012;4(4):204-9.

73. Kumagae N, Komada W, Fukui Y, Okada D, Takahashi H, Yoshida $\mathrm{K}$, et al. Influence of the flexural modulus of prefabricated and experimental posts on the fracture strength and failure mode of composite resin cores. Dent Mater J. 2012;31(1):113-9.

74. Mankar S, Kumar N, Karunakaran J, Kumar S. Fracture resistance of teeth restored with cast post and core: an in vitro study. J Pharm Bioallied Sci. 2012;4:S197-202.

75. Mehrvarzfar P, Rezvani Y, Jalalian E. Comparison of resilon and gutta-percha filling materials on root canal fracture resistance following restoring with quartz fiber posts. J Dent (Tehran). 2012;9(2):156-61.

76. Nie EM, Chen XY, Zhang CY, Qi LL, Huang YH. Influence of masticatory fatigue on the fracture resistance of the pulpless teeth restored with quartz-fiber post-core and crown. Int J Oral Sci. 2012;4(4):218-20.

77. Rosa R, Hwas MSDA, Melo D, Valandro LF, Kaizer O. Fracture strength of endodontically treated teeth restored with different strategies after mechanical cycling. Gen Dent. 2012;60:e62-8.
78. Rotunno F, Rotunno E. In vitro comparison of the mechanical strength of carbon fiber and zirconia ceramic posts and cores. Int J Periodontics Restor Dent. 2012;32(2):e75-81.

79. Schiavetti R, Sannino G. In vitro evaluation of ferrule effect and depth of post insertion on fracture resistance of fiber posts. Comput Math Methods Med. 2012;2012.

80. Sterzenbach G, Rosentritt M, Frankenberger R, Paris S, Naumann M. Loading standardization of postendodontic restorations in vitro: impact of restorative stage, static loading, and dynamic loading. Oper Dent. 2012;37(1):71-9.

81. Tunjan R, Rosentritt M, Sterzenbach G, Happe A, Frankenberger R, Seemann R, et al. Are endodontically treated incisors reliable abutments for zirconia-based fixed partial dentures in the esthetic zone? J Endod. 2012;38(4):519-22.

82. Zicari F, Van Meerbeek B, Scotti R, Naert I. Effect of fibre post length and adhesive strategy on fracture resistance of endodontically treated teeth after fatigue loading. J Dent. 2012;40(4):312-21.

83. Ayad MF, Bahannan SA, Rosenstiel SF. Influence of irrigant, dowel type, and root-reinforcing material on fracture resistance of thin-walled endodontically treated teeth. $\mathrm{J}$ Prosthodont. 2011;20(3):180-9.

84. Carlini-Jr B, Cecchin D, Pereira GD da S, Paulillo LAMS. Influence of remaining coronal structure and finish line on the fracture strength of roots restored with metallic posts. Braz Oral Res. 2011;25(4):345-50.

85. Kathuria A, Khetarpal S, Kavitha M. Ex vivo fracture resistance of endodontically treated maxillary central incisors restored with fiber-reinforced composite posts and experimental dentin posts. J Conserv Dent. 2011;14(4):401.

86. Khatter R, Singh R, Sroa R. Rigidity, retention, and resistance of titanium versus double taper light root canal posts: an in vitro evaluation. Indian J Dent Res. 2011;22:879.

87. Li Q, Xu B, Wang Y, Cai Y. Effects of auxiliary fiber posts on endodontically treated teeth with flared canals. Oper Dent. 2011;36(4):380-9.

88. Makade CS, Meshram GK, Warhadpande M, Patil PG. A comparative evaluation of fracture resistance of endodontically treated teeth restored with different post core systems - an in-vitro study. J Adv Prosthodont. 2011;3(2):90-5.

89. Mangold JT, Kern M. Influence of glass-fiber posts on the fracture resistance and failure pattern of endodontically treated premolars with varying substance loss: An in vitro study. J Prosthet Dent. 2011;105(6):387-93.

90. Naumann M, Sterzenbach G, Rosentritt M, Beuer F, Meyer-Lückel H, Frankenberger R. Self-adhesive cements as core build-ups for one-stage post-endodontic restorations? Int Endod J. 2011;44(3):195-202.

91. Ni CW, Chang CH, Chen TYF, Chuang SF. A multiparametric evaluation of post-restored teeth with simulated bone loss. J Mech Behav Biomed Mater. 2011;4(3):322-30.

92. Nothdurft FP, Schmitt T, Rupf S, Pospiech PR. Influence of fatigue testing and cementation mode on the load-bearing capability of bovine incisors restored with crowns and FRC posts. Dent Mater J. 2011;30:109-14.

93. Santana FR, Castro CG, Simamoto-Júnior PC, Soares P V., Quagliatto PS, Estrela C, et al. Influence of post system and remaining coronal tooth tissue on biomechanical behaviour of root filled molar teeth. Int Endod J. 2011;44(5):386-94.

94. Santini MF, Wandscher V, Amaral M, Baldissara P, Valandro LF. Mechanical fatigue cycling on teeth restored with fiber posts: impact of coronal grooves and diameter of glass fiber post on fracture resistance. Minerva Stomatol. 2011;60:485-93.

95. Sherfudhin H, Hobeich J, Carvalho CA, Aboushelib MN, Sa$\operatorname{dig} \mathrm{W}$, Salameh Z, et al. Effect of different ferrule designs on 
the fracture resistance and failure pattern of endodontically treated teeth restored with fiber posts and all-ceramic crowns. J Appl Oral Sci. 19(1):28-33.

96. Silva GR, Santos-Filho PC de F, Simamoto-Júnior PC, Martins LRM, da Mota AS, Soares CJ. Effect of post type and restorative techniques on the strain and fracture resistance of flared incisor roots. Braz Dent J. 2011;22(3):230-7.

97. Solomon CS, Osman YI. In vitro comparison of endodontic posts in structurally compromised roots of maxillary incisors. SADJ. 2011;66(5):220-3.

98. Chuang SF, Yaman P, Herrero A, Dennison JB, Chang CH. Influence of post material and length on endodontically treated incisors: An in vitro and finite element study. J Prosthet Dent. 2010;104(6):379-88.

99. Silva NR, Raposo LHA, Versluis A, Fernandes-Neto AJ, Soares CJ. The effect of post, core, crown type, and ferrule presence on the biomechanical behavior of endodontically treated bovine anterior teeth. J Prosthet Dent. 2010;104(5):306-17.

100. Torbjörner A, Fransson B. A literature review on the prosthetic treatment of structurally compromised teeth. Int $\mathrm{J}$ Prosthodont. 2004;17(3):369-76.

101. Okeson J. Criteria for optimum functional occlusion. In: Management of Temporomandibular Disorders and Occlusion. 7th ed. 2013. p. 73-85.

102. Teruel JD, Alcolea A, Hernández A, Ruiz AJO. Comparison of chemical composition of enamel and dentine in human, bovine, porcine and ovine teeth. Arch Oral Biol. 2015;60(5):768-75.

103. Yassen GH, Platt JA, Hara AT. Bovine teeth as substitute for human teeth in dental research: a review of literature. $\mathrm{J}$ Oral Sci. 2011;53(3):273-82.

104. Soares CJ, Pizi EC, Fonseca RB, Martins LR. Influence of root embedment material and periodontal ligament simulation on fracture resistance tests. Braz Oral Res. 2005;19(1):11-6.

105. Mamoun JS. On the ferrule effect and the biomechanical stability of teeth restored with cores, posts, and crowns. Eur J Dent. 2014;8(2):281-6.

106. Zicari F, Van Meerbeek B, Debels E, Lesaffre E, Naert I. An up to 3-year controlled clinical trial comparing the outcomeof glass fiber posts and composite cores with gold alloy-based posts and cores for the restoration of endodontically treated teeth. Int J Prosthodont. 2011;24(4):363-72.

107. Juloski J, Fadda GM, Monticelli F, Fajó-Pascual M, Goracci C, Ferrari M. Four-year survival of endodontically treated premolars restored with fiber posts. J Dent Res. 2014;93(7S):52S-58S.

108. Ferrarri M, Vichi A, Fadda GM, Cagidiaco MC, Tay FR, Breschi L, et al. A randomized controlled trial of endodontically treated and restored premolars. J Dent Res. 2012;91(7S):72S-88S.

109. Kelly JR, Rungruanganunt P, Hunter B, Vailati F. Development of a clinically validated bulk failure test for ceramic crowns. J Prosthet Dent. 2010;104(4):228-38.

110. Padipatvuthikul P, Mair LH. Comparison of Shear Bond Strength, Fatigue Limit and Fatigue Life in resin-bonded metal to enamel bonds. Dent Mater. 2008;24(5):674-80.

111. Nishigawa K, Bando E, Nakano M. Study of bite force during sleep associated bruxism. Nihon Hotetsu Shika Gakkai Zasshi. 1998;42(5):740-6.

112. Wiskott HWA, Meyer M, Perriard J, Scherrer SS. Rotational fatigue-resistance of seven post types anchored on natural teeth. Dent Mater. 2007;23(11):1412-9.

113. Baran G, Boberick K, McCool J. Fatigue of restorative materials. Crit Rev Oral Biol Med. 2001;12(4):350-60.
114. Collins J. Fatigue testing pocedures and statistical interpretations of data. In: Failure of Materials in Mechanical Design. 2nd ed. John Wiley \& Sons; 1993. p. 374-92.

115. Magne P, Carvalho A, Bruzi G, Anderson R, Maia H, Giannini M. Influence of no-ferrule and no-post buildup design on the fatigue resistance of endodontically treated molars restored with resin nanoceramic $\mathrm{CAD} / \mathrm{CAM}$ crowns. Oper Dent. 2014;39(6):595-602.

116. Dixon WJ, Mood AM. A method for obtaining and analyzing sensitivity data. J Am Stat Assoc. 1948;43:109-26.

117. Kelly JR. Clinically relevant approach to failure testing of all-ceramic restorations. J Prosthet Dent. 1999;81(6):652-61.

118. Mair L, Padipatvuthikul P. Variables related to materials and preparing for bond strength testing irrespective of the test protocol. Dent Mater. 2010;26:e17-23.

119. Ferrario VF, Sforza C, Serrao G, Dellavia C, Tartaglia G. Single tooth bite forces in healthy young adults. J Oral Rehabil. 2004;31:18-22.

120. Wiskott HW, Nicholls JI, Belser UC. Stress fatigue: basic principles and prosthodontic implications. Int J Prosthodont. 1995;8(2):105-16.

121. Po JMC, Kieser JA, Gallo LM, Tésenyi AJ, Herbison P, Farella M. Time-frequency analysis of chewing activity in the natural environment. J Dent Res. 2011;90(10):1206-10.

122. Stewardson DA, Shortall AC, Marquis PM. The effect of clinically relevant thermocycling on the flexural properties of endodontic post materials. J Dent. 2010;38:437-42.

123. Gale MS, Darvell BW. Thermal cycling procedures for laboratory testing of dental restorations. J Dent. 1999;27(2):89-99.

124. INTERNATIONAL ORGANIZATION FOR STANDARDIZATION (ISO). Dental materials - guidance on testing of adhesion to tooth structure - ISO TR 11405:1994. In Switzerland; 1994.

125. Pauls HJ. Lingual orthodontics with orthognathic surgery in a severe class II, division 2 case. J Orofac Orthop. 2008;69(2):135-45.

126. González-Lluch C, Pérez-González A, Sancho-Bru JL, Rodríguez-Cervantes P-J. Mechanical performance of endodontic restorations with prefabricated posts: sensitivity analysis of parameters with a 3D finite element model. Comput Methods Biomech Biomed Engin. 2012;17(10):1108-18.

127. Silva GR, Silva NR, Soares PV, Costa AR, Fernandes-Neto AJ, Soares CJ. Influence of different load application devices on fracture resistance of restored premolars. Braz Dent J. 2012;23(5):484-9.

128. Falagas ME, Pitsouni EI, Malietzis GA, Pappas G. Comparison of PubMed, Scopus, Web of Science, and Google Scholar: strengths and weaknesses. FASEB J. 2008;22(2):338-42.

129. Kim JW, Covel NS, Guess PC, Rekow ED, Zhang Y. Concerns of hydrothermal degradation in $\mathrm{CAD} / \mathrm{CAM}$ zirconia. $\mathrm{J}$ Dent Res. 2010;89(1):91-5.

130. Zhou L, Wang Q. Comparison of fracture resistance between cast posts and fiber posts: a meta-analysis of literature. $\mathrm{J}$ Endod. 2013;39(1):11-5.

\section{Endereço para correspondência:}

Sara Fraga

Duque de Caxias, 1295/803

97015-190 Santa Maria RS - Brazil

Fone: (55) 9134-4516 / (55)-3220-9272

E-mail: sara.odonto@yahoo.com.br

Recebido: 12/01/2017. Aceito: 19/03/2017. 